\title{
Climate Friendly Urban Green Areas: Roadside Green Spaces in Sakarya/Turkey
}

\author{
Hande Sanem ÇINAR ${ }^{1}$, Nebahat Nihan PARLAK ${ }^{1}$, Nazlı YILDIZ DÖNMEZ ${ }^{1}$ \\ ${ }^{1}$ Departement of Landscape Planning and Design, Landscape Architecture Division, Istanbul University
}

\begin{tabular}{|c|c|}
\hline Article Info & ABSTRACT \\
\hline Article history: & The role of urban green areas to adapt climate change impacts has been \\
\hline Received Sept 27, 2018 & emphasized globally as urbanization is a very common fact around the world. \\
\hline Revised Dec 14, 2018 & studies also underlined that sustainable urban planning is a crucial issue to \\
\hline Accepted Dec 17, 2018 & enable more livable cities. The most natural and sustainable solution is to \\
\hline Keyword: & $\begin{array}{l}\text { xeriscape. In this study we focus on roadside green spaces in an industrialized } \\
\text { city. Traffic islands have been assessed based on the share of hardscape and }\end{array}$ \\
\hline Xeriscape & green parts together with plant species and their irrigation specifications. The \\
\hline Climate change & irrigation requirements have been analyzed by using a potential \\
\hline Sustainable development & evapotranspiration method which is Blaney Criddle equation. The need for \\
\hline Urban green space & $\begin{array}{l}\text { irrigation and the influence of the roadside green spaces as an adaptation tool } \\
\text { emerge as a controversial situation in case of low water resources. We }\end{array}$ \\
\hline Traffic island & $\begin{array}{l}\text { analyzed water needs of current plantation and irrigation systems and came } \\
\text { plants and grey water has a good potential to optimize water usage, mitigate } \\
\text { urban heat island effect and support adaptation to the climate change. }\end{array}$ \\
\hline
\end{tabular}

\section{Corresponding Author:}

Nebahat Nihan PARLAK,

Departement of Landscape Departement of Landscape Planning and Design,

Landscape Architecture Division,

Istanbul University

İstanbul Üniversitesi Orman Fakültesi Valide Sultan Cad. No:1 34473

Bahçeköy-Sarıyer/ISTANBUL/TÜRKIYE

Email: nihan.parlak@istanbul.edu.tr

\section{Introduction}

In the research, it is stated that the hot air waves in the world are getting warmer in the last decade and the period between 1983 and 2012 is the hottest 30 years period of 1400 years [1]. Projections made for our country also indicate that climate change will lead to a decrease in precipitation on many provinces, and an increase in temperature and evapotranspiration. At the Rio +20 summit held by the United Nations in 2012, 17 'Sustainable Development Goals', which are aimed to be realized in the world between 2015 and 2030 and integrated with the 'Millennium Development Goals', have been determined. Xeriscaping studies, making the cities sustainable, struggle with climate change and its effects can be seen among these targets [2]. The xeriscaping implementation has a critical importance for that. The struggle with the effects of climate change on cities [3,4], and the effects of heat islands formed by surplus of hard surfaces have become the subject of various studies [5,6,7]. The comprehensive implementation of surveys in urban green areas for the efficient use of water and the introduction of sustainable landscape studies should be the most important task of landscape architects. 


\subsection{Traffic Islands}

Traffic islands; are the navigating, divisive and canalizing areas of the traffic flow, taking into account the safety of people [8]. In fact, it is important to use the resources of the traffic islands, which have large areas, efficiently. However, work done by municipalities usually involves a lot of time, energy [9], water and fossil fuel consumption in the area. Particularly as a precaution, the size and branching of selected plants should be taken into consideration and the use of highly reflective and shiny surfaces should be avoided. In addition, the use of natural plant species in the field will reduce watering and maintenance costs.

\section{Material and Methods}

\subsection{Material}

In the study, traffic islands organized by the Sakarya provincial Park and Gardens Directorate were tried to be evaluated in terms of effective use of water. Determination of living and non-living materials used in the study, determination of irrigation applications, and determination of the availability of the works to the xeriscaping and solution proposal are presented. It has been assessed by the proposals that traffic islands can be created to save time, money and water, to reduce water footprint, to support the struggle with climate change and adaptation processes, and help keeping underground spring waters clean.

\subsubsection{Research Area}

Sakarya occupies $0,62 \%$ of Turkey's land. It is surrounded by Düzce province in the east, Bilecik province in the south, Kocaeli province in the west and the Black Sea in the north [10]. As a research area, 5 sample traffic islands were chosen in the Serdivan district of Sakarya province (Figure 1).

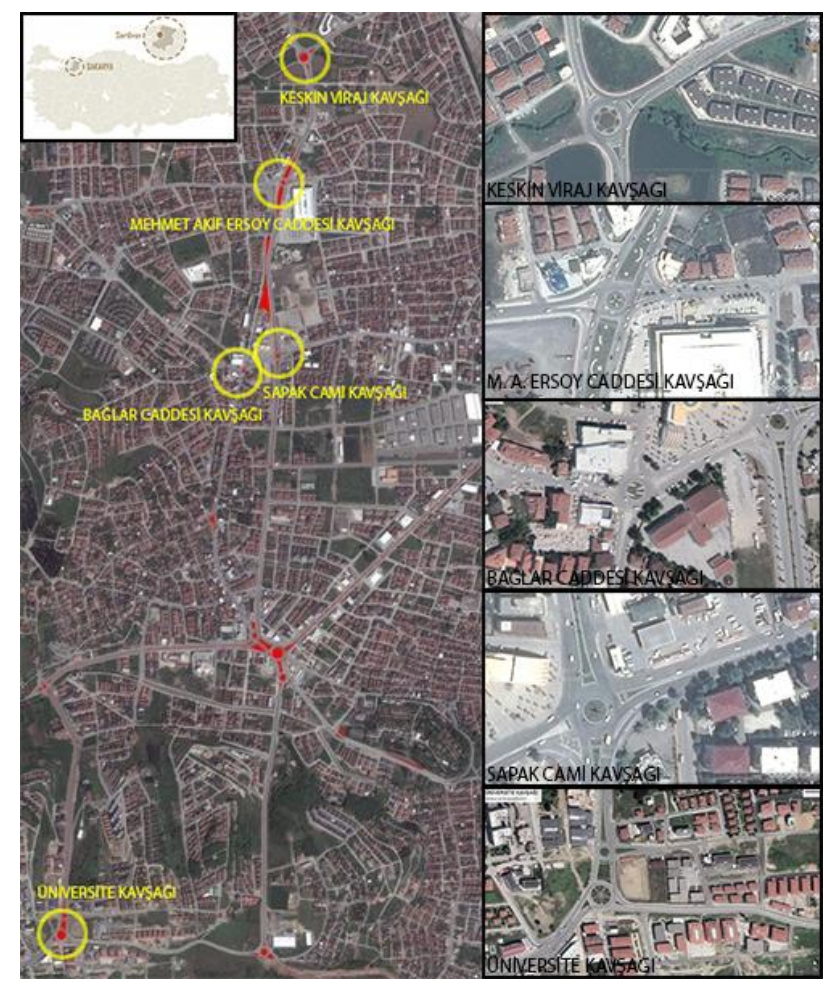

Figure 1. Location of intersections and aerial photograph (composed from [11].)

\subsubsection{Climatic Characteristics}

The fact that the average and absolute temperature differences during the year are less indicates that the region is a transition area between the Mediterranean and Black Sea climate regions. In addition, the province that has Marmara climate characteristics has a rainy, moist and mild climate. The average annual temperature is $14.4^{\circ} \mathrm{C}$, the lowest temperature is $-14.5^{\circ} \mathrm{C}$, and the highest temperature is $41.8^{\circ} \mathrm{C}$. The average annual humidity is $73.9 \%$ and the average annual precipitation is $1,016 \mathrm{~mm}$. 
According to the Köppen Climate Classification, the province belongs to "warm winter, dry and warm summer" class and according to the Martonne Climate Classification; it belongs to "half moist" class [2]. According to RCP8.5 scenario; it was estimated that the average annual temperature of Sakarya would increase by 3 degrees between 2013 and 2014 (Figure 2) and the annual average rainfall would decrease by $40 \%$.
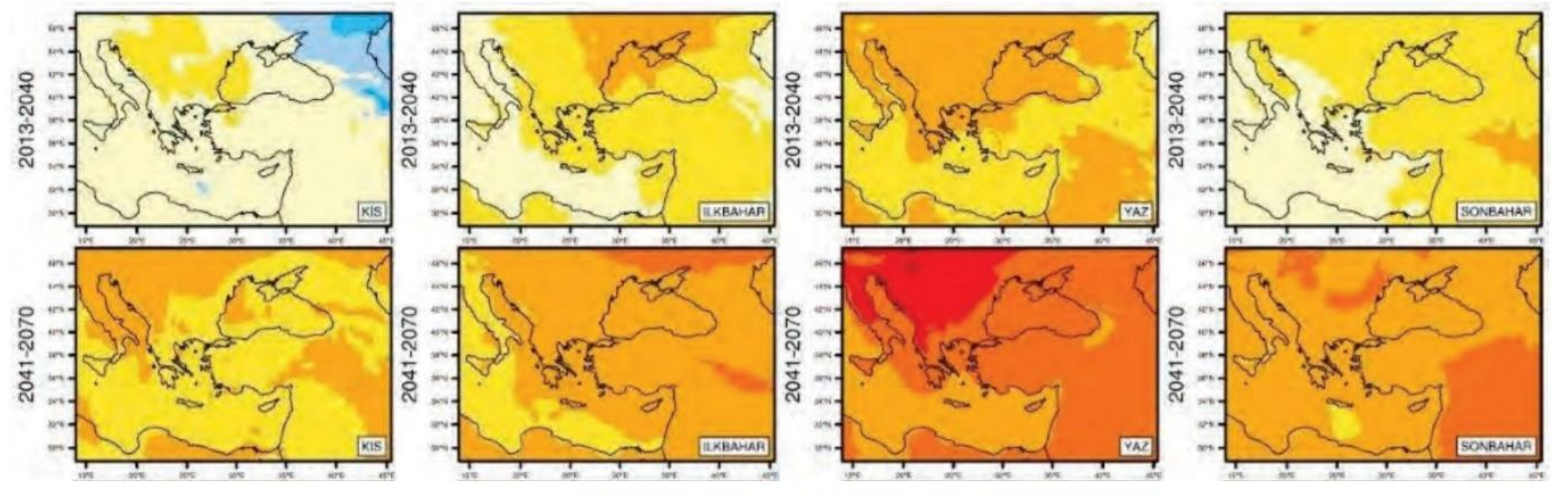

HadGEM2-ES/RCP4.5

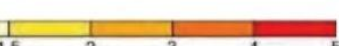

Figure 2. Temperature projections according to RCP 8.5 (rearranged from [12].)

\subsubsection{Flora}

The amount of active green area in the province is $4.553 .171,65 \mathrm{~m}^{2}$. Within the green areas; urban parks, neighborhood parks, traffic islands, and squares are included. The amount of green space created by traffic islands is $555.111 .74 \mathrm{~m}^{2}$. In Serdivan district, which is selected as the study area, $\mathrm{m}^{2}$ of the green areas constituting traffic islands is $104,487,18$. In the district, the total green area of the sample traffic island is $5173,70 \mathrm{~m}^{2}$. The Zoning Law states that the amount of green space per capita should be $10 \mathrm{~m}^{2}$, but for Sakarya this amount is $4.66 \mathrm{~m}^{2}$ (Table 1 ).

Table 1. Plants used in central refuges and traffic islands by the Sakarya Metropolitan Municipality.

\begin{tabular}{|c|c|c|c|c|c|c|c|c|c|c|c|c|}
\hline \multirow{3}{*}{ 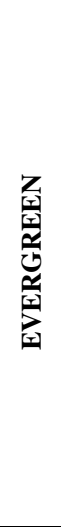 } & 泾 & $\begin{array}{l}\text { Pinus } \\
\text { nigra }\end{array}$ & \multirow{3}{*}{ 尝 } & $\begin{array}{c}\text { Buxus } \\
\text { sempervir } \\
\text { ens }\end{array}$ & $\begin{array}{c}\text { Euonym } \\
\text { us } \\
\text { Japonica } \\
\text { "Aurea" }\end{array}$ & $\begin{array}{c}\text { Picea } \\
\text { punge } \\
\text { ns } \\
\text { Glauc } \\
\text { a } \\
\text { Globo } \\
\text { sa } \\
\text { Nana" }\end{array}$ & $\begin{array}{c}\text { Pittosporu } \\
\text { m tobira } \\
\text { Nana" }\end{array}$ & $\begin{array}{l}\text { Pinus } \\
\text { mugo }\end{array}$ & $\begin{array}{l}\text { Prun } \\
\text { us } \\
\text { lauro } \\
\text { ceras } \\
\text { sus }\end{array}$ & $\begin{array}{c}\text { Buxus } \\
\text { semperviren } \\
\mathrm{s}\end{array}$ & $\begin{array}{c}\text { Euonym } \\
\text { us } \\
\text { Japonica } \\
\text { "Aurea" }\end{array}$ & $\begin{array}{c}\text { Picea } \\
\text { pungens } \\
\text { Glauca } \\
\text { Globosa } \\
\text { Nana" }\end{array}$ \\
\hline & 空 & Tree & & Shrub & Shrub & Shrub & Shrub & Shrub & Tree & Shrub & Shrub & Shrub \\
\hline & 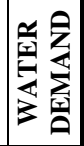 & Low & & High & Medium & $\underset{\mathrm{m}}{\text { Mediu }}$ & Medium & Medium & High & High & Medium & Medium \\
\hline \multirow{3}{*}{ 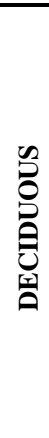 } & 空 & $\begin{array}{c}\text { Acer } \\
\text { campestre }\end{array}$ & $\begin{array}{c}\text { Betula } \\
\text { pendu } \\
\text { la }\end{array}$ & $\begin{array}{c}\text { Carpinus } \\
\text { betulus }\end{array}$ & $\begin{array}{c}\text { Chamaer } \\
\text { ops } \\
\text { excelsa }\end{array}$ & $\begin{array}{l}\text { Fraxin } \\
\text { us } \\
\text { excels } \\
\text { ior }\end{array}$ & $\begin{array}{c}\text { Hibiscus } \\
\text { syriacus }\end{array}$ & $\begin{array}{c}\text { İlex } \\
\text { aquifolium }\end{array}$ & $\begin{array}{c}\text { Ligu } \\
\text { stru } \\
\mathrm{m} \\
\text { japo } \\
\text { nicu } \\
\mathrm{m}\end{array}$ & $\begin{array}{c}\text { Liquidamba } \\
\mathrm{r} \\
\text { styracifolia }\end{array}$ & $\begin{array}{c}\text { Magnoli } \\
\text { a } \\
\text { grandifl } \\
\text { ora }\end{array}$ & $\begin{array}{c}\text { Malus } \\
\text { floribund } \\
\text { a }\end{array}$ \\
\hline & 空 & Tree & Tree & Tree & Tree & Tree & Tree & Tree & Tree & Tree & Tree & Tree \\
\hline & 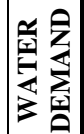 & Medium & $\begin{array}{c}\text { Mediu } \\
\mathrm{m}\end{array}$ & High & $\mathrm{Az}$ & Low & $\begin{array}{c}\text { Low/Medi } \\
\text { um }\end{array}$ & Medium & Low & Medium & Medium & High \\
\hline
\end{tabular}




\begin{tabular}{|c|c|c|c|c|c|c|c|c|c|c|c|}
\hline \multirow{3}{*}{ 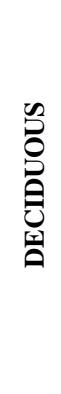 } & 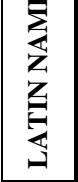 & $\begin{array}{c}\text { Melia } \\
\text { azedarach }\end{array}$ & $\begin{array}{c}\text { Neriu } \\
\mathrm{m} \\
\text { oleand } \\
\text { er }\end{array}$ & $\begin{array}{l}\text { Olea } \\
\text { euroea }\end{array}$ & $\begin{array}{c}\text { Quercus } \\
\text { ilex }\end{array}$ & $\begin{array}{c}\text { Platan } \\
\text { us } \\
\text { orient } \\
\text { alis }\end{array}$ & $\begin{array}{l}\text { Photinia } \\
\text { fraserrii }\end{array}$ & $\begin{array}{l}\text { Prunus } \\
\text { calleryna } \\
\text { "Chanticle } \\
\text { er }\end{array}$ & $\begin{array}{l}\text { Prun } \\
\text { us } \\
\text { persi } \\
\text { ca }\end{array}$ & $\begin{array}{l}\text { Robinia } \\
\text { pse. } \\
\text { "Umbraculi } \\
\text { fera" }\end{array}$ & $\begin{array}{l}\text { Tilia } \\
\text { cordota }\end{array}$ \\
\hline & 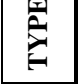 & Tree & Tree & Tree & Tree & Tree & Tree & Tree & Tree & Tree & Tree \\
\hline & 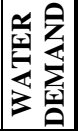 & Medium & $\begin{array}{l}\text { Low/ } \\
\text { Mediu } \\
\text { m }\end{array}$ & Low & Medium & $\begin{array}{c}\text { Mediu } \\
\mathrm{m}\end{array}$ & Medium & Medium & $\begin{array}{l}\text { Medi } \\
\text { um }\end{array}$ & $\begin{array}{c}\text { Low/Mediu } \\
\text { m }\end{array}$ & $\begin{array}{c}\text { Low/Me } \\
\text { dium }\end{array}$ \\
\hline
\end{tabular}

\subsection{Method}

To determine the months that need for irrigation in the study, long term monthly rainfall data were compared with potential evapotranspiration values according to the Blaney Criddle method. According to the method; the main factors affecting the water needs of plants are temperature, humidity, wind speed, sunrise duration and intensity. Total potential evapotranspiration calculation is;

ETo $=p(0.46$ Tort +8$)$

ETo $=$ Reference plant evapotranspiration value $(\mathrm{mm} /$ day). For grass from 8 to $15 \mathrm{~cm}$

Tort $=$ Average daily temperature value $\left({ }^{\circ} \mathrm{C}\right)$

$p=$ the daily percentage value of the annual time of the day,

The average daily temperature value is subtracted from the monthly average values, and the $\mathrm{p}$ value is calculated separately for each month according to the latitude. Green area data are arranged in AUTOCAD and NETCAD media to determine total green area quantities. Plant species in the study area have been identified and photographed. Drought parameters have been established in the study; and the most suitable traffic island was selected for the xeriscaping by evaluating in terms of aesthetics, functionality, sustainability, drought tolerance, etc.

\section{Results}

\subsection{Precipitation-Evapotranspiration Analysis}

According to the climate parameters of Sakarya, annual rainfall is $838.9 \mathrm{~mm}$ and the rainiest months are December and January. The months are July and August when the precipitation is the lowest but the temperature is the highest (Table 2).

Table 2. Values for the province of Sakarya between 1926 and 2016 [13].

\begin{tabular}{|c|c|c|c|c|c|c|c|c|c|c|c|c|c|c|}
\hline & & Jan & Feb & Mar & Apr & May & Jun & Jul & Aug & Sep & Oct & Nov & Dec & Annual \\
\hline \multicolumn{2}{|c|}{ Average Temperature $\left({ }^{\circ} \mathrm{C}\right)$} & 6.1 & 6.7 & 8.5 & 13 & 17.4 & 21.5 & 23.4 & 23.2 & 19.6 & 15.4 & 11.5 & 8.1 & 14.5 \\
\hline $\begin{array}{l}\text { Average } \\
\text { Temperature }\left({ }^{\circ} \mathrm{C}\right)\end{array}$ & Maximum & 9.7 & 11 & 13.7 & 18.9 & 23.4 & 27.5 & 29.3 & 29.4 & 26.3 & 21.2 & 16.6 & 11.9 & 19.9 \\
\hline $\begin{array}{l}\text { Average } \\
\text { Temperature }\left({ }^{\circ} \mathrm{C}\right)\end{array}$ & Minimum & 2.9 & 3.2 & 4.5 & 8.1 & 12.2 & 15.7 & 17.8 & 17.8 & 14.3 & 10.9 & 7.4 & 4.9 & 10 \\
\hline $\begin{array}{l}\text { Average Sunshine } \\
\text { (hour) }\end{array}$ & Duration & 2.3 & 3.1 & 3.6 & 5.1 & 6.4 & 8.2 & 8.6 & 8.3 & 6.6 & 4.3 & 3.2 & 2.3 & 62 \\
\hline Average Number of $\mathrm{R}$ & Rainy Days & 15.2 & 13.9 & 13.4 & 11.2 & 9.8 & 8 & 5.7 & 5.7 & 7.3 & 11.1 & 11.9 & 15.4 & 128.6 \\
\hline Average Precipitatior & $\mathrm{n}(\mathrm{mm})$ & 94.6 & 76.3 & 76.1 & 59 & 50.7 & 70.1 & 48.3 & 45.6 & 53.8 & 79 & 77.9 & 107.5 & 838.9 \\
\hline
\end{tabular}


According to the Blaney Cridde method; when the calculated monthly minimum potential exapotranspiration values (low wind speed and sunbath conditions) are compared with rainfall critical periods on water need of plants can be determined. When compared with the monthly rainfall and the potential ET, it is observed that the total evaporation rate has increased since April and this situation has continued until October (Figure 3).

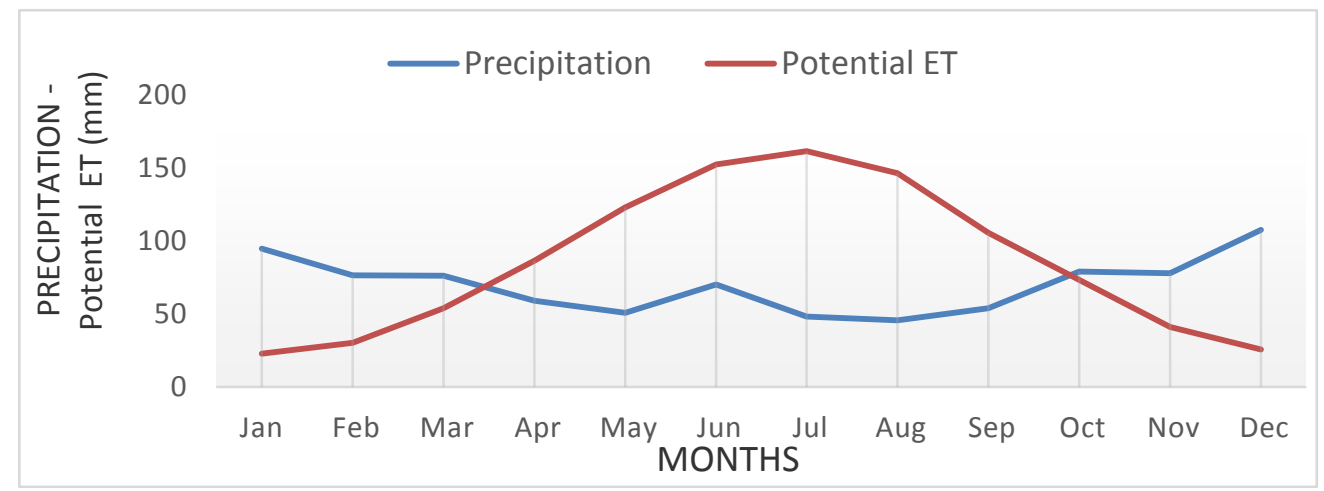

Figure 3. Comparison of monthly precipitation and evapotranspiration values.

Potential ET value in July is higher than $5.2 \mathrm{~mm}$ per day even in low wind and sun conditions for grass areas and $10.9 \mathrm{~mm}$ in strong wind and sun conditions (Table 3). It suggests that irrigation will be needed between April and October. July is the month in which the need for irrigation is highest.

Table 3. Comparison of potential min ET values and precipitation for Sakarya and grass daily minimum (DWDmin) ve maximum (DWDmax) water demand values for grass areas within the Sakarya province.

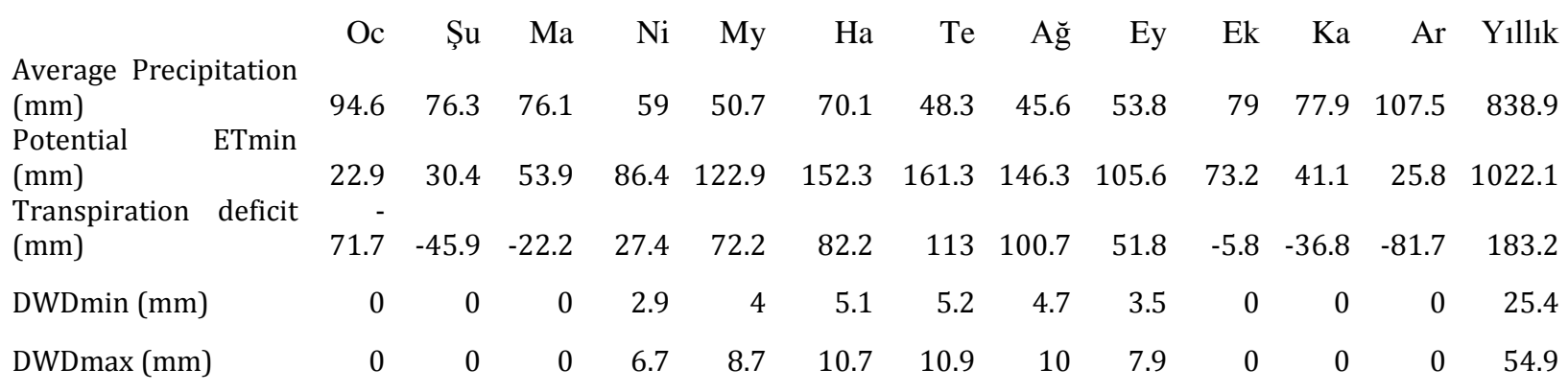

\subsection{Drought Parameter in Serdivan District}

The suitability of 5 traffic islands in Serdivan District for xeriscaping has been examined. The surrounding landscape materials are rated according to their water requirements and their functional suitability. And when the rate is done, the materials are divided into categories such as plants, mulching and grass. In the rate, materials with high water demand were given +1 , medium ones were 0 , and materials with low water were -1 . In the case of functional suitability, those who are suitable for use are given +1 , those who are moderately suitable are given 0 , and those who are not suitable are given -1 . In evaluating plant material in functional suitability; the form of the plant used, whether it is suitable for pruning, whether it is resistant to exhaust gases or not obstructing the view have been taken into consideration. Trees, slag and pumice stone were identified as mulching materials in the area. Among these materials, slag is the best in terms of both water demand and functional suitability because the slag is trapped in excess water and has the property of protecting the soil's wet and returning the water when the plant needs it. It is suitable for junctions because it does not have features such as flying and light reflection when used in junctions [14]. There is no water demand for Pumice stone and bark, but Pumice stone cannot absorb water from its thick textured structure; because the bark is a very light material, it is more likely to fly. This situation is a disadvantage for traffic (Table3.3); 
1. Sapak Mosque Junction: The total $\mathrm{m}^{2}$ is $345,56.139,87 \mathrm{~m}^{2}$ belongs to green area, 205,69 $\mathrm{m}^{2}$ belongs to slag. Buxus microohylus is the species that requires the most water from plants. Picea Pungens "globosa nana" plant has moderate water demand; Taxus baccata has less water demand. The most suitable plant in terms of function is Buxus microphyllus because it is favorable with pruning but it is a wrong choice with the reason why there is a surplus of water demand. The Taxus baccata plant is also suitable for pruning, but the pyramid form is above the eyes of the drivers and prevents the vision. Picea pungens the "globosa nana" plant is an expensive plant that does not interfere with its field of view, but it loses its functional properties due to its leaves being affected by the exhaust. It is a positive situation that the mulch material at the junction has been used more than the grass. The score of the junction is (-1). It is the most xerophytic among the evaluated junctions.

2. Mehmet Akif Ersoy Street Junction: The total $\mathrm{m}^{2}$ is $314,56.21 \mathrm{~m}^{2}$ belong to bark, $45 \mathrm{~m}^{2}$ belong to pumice stone, $24 \mathrm{~m}^{2}$ belong to seasonal flowers and $224,56 \mathrm{~m}^{2}$ belong to grass area. There are different forms of Taxus baccata plant as plant material at the junctions. The plant's water demand is low. However, it is not appropriate to evaluate at the junction with the reason that it is an expensive plant. At the same time seasonal flowers' water need and care are also high. When the plant is rated according to the mulch and grass materials it gets (-2) point.

3. Sharp Bend Junction: The total $\mathrm{m} 2$ is $2759,11 \mathrm{~m}^{2} .300 \mathrm{~m} 2$ belong to bark, $150 \mathrm{~m}^{2}$ belong to podima pebble, $2309 \mathrm{~m}^{2}$ belong to grass area. Magnolia grandiflora, Olea europea and seasonal flowers were used as plant material. Magnolia grandiflora is not suitable functional because the water demands is moderate and it obstructs the view. The water demand of Olea europea is less but it is not suitable for using in the area. The rate has been determined as (-3). Grass area $\mathrm{m}^{2}$ is much higher than mulching materials. This causes too much water consumption.

4. Bağlar Street Junction: The total area is $254.47 \mathrm{~m}^{2}$. The grass area is $167,28 \mathrm{~m}^{2}$, the used mulch material is $87,19 \mathrm{~m}^{2}$. The only plant used is the Buxus microphyllus, which has high water demand. The total drought parameter is $(-3)$.

5. University Junction: The total area is $1500 \mathrm{~m}^{2}$. The grass area is $710,26 \mathrm{~m}^{2}$. Taxus baccata and Chamaerops excelsa plants that have less and moderate water demand are used in the area. Bark and pumice stone are used as mulching material. The grass area is much. The rate is $(-2)$.

\subsection{Discussion and Conclusions}

In our country, the effect of global warming increases the importance of water resources and it needs to be used today and in the future to meet the demand. Especially traffic islands are areas that have the greatest need and maintenance of water as a result of unconscious regulations. In Sakarya, which is the study area, the amount of green area that constitutes traffic islands is $555.111 .74 \mathrm{~m}^{2}$. The water needs of the mainly used species in these traffic islands, which have a large green area in terms of city, are mostly moderate and high level. It has been observed that grass areas and seasonal flowers are used intensively in traffic islands. Mulching materials are slag, pumice stone, and bark. The use of mulching is an achievement in terms of xeriscaping [15]. However, it is noticed that these materials are used for decorative purposes only, not for saving water. One of the most important principles of xeriscaping is the necessity of using natural plants. In this way, both maintenance and water savings can be achieved. However, most of the plants used in traffic islands are exotic. This leads to more water consumption, to the use of more nutrients, and to the contamination of groundwater by the mixing of nutrients into the soil.

The amount of green area of traffic islands within the scope of the research is $5173.70 \mathrm{~m}^{2}$. The green areas in the traffic islands are generally irrigated in every 3 days from 11 March to 31 May, every day from 1 June to 30 August, and every 3 days from 1 September to 31 October. But these days vary according to seasonal conditions. In areas where automatic irrigation is performed, the water requirement for $1 \mathrm{~m} 2$ is 3,32 lt. The average annual irrigation is conducted in 140 days. In this context, automatic irrigation is performed in the sample traffic areas. The total grass area at these junctions is $3550,97 \mathrm{~m}^{2}$. If the water requirement for $1 \mathrm{~m}^{2}$ is $3.32 \mathrm{lt}$, the daily water requirement is $3550.97 \times 3.32=11.789,52 \mathrm{lt}$. Since the annual number of irrigation days is 140 and the daily water consumption of these areas is about 11.8 tons, the annual water consumption in 
these areas is about $140 \times 11.8=1652$. When the grass areas in the sampling area are reduced by $50 \%$ and the half area is used as grass that has less water demand; the grass area will be $1775,48 \mathrm{~m} 2$ and the daily water consumption will be $1,775,48 \times 3.32=5,894,59 \mathrm{lt}$. The area with a daily water consumption of about 5.90 tons will have an annual water requirement of 5.90x140 = 826 tons, and when the grass area is reduced to half, the grass water will gain 826 tons of water. If thirst-free plants resistant to thirst are used on all grass areas, more water consumption will be gained. For example, if the $3550.97 \mathrm{~m} 2$ area was designed with a lawn rather than grass, the watering of these areas was reduced by $1 / 4$ and watered for 35 days. In this case the daily water requirement is $3550.97 \times 3.32=11,789.52 \mathrm{lt}$.

Table 4. Xeriscape landscape scoring of sample intersection in the district of Serdivan.

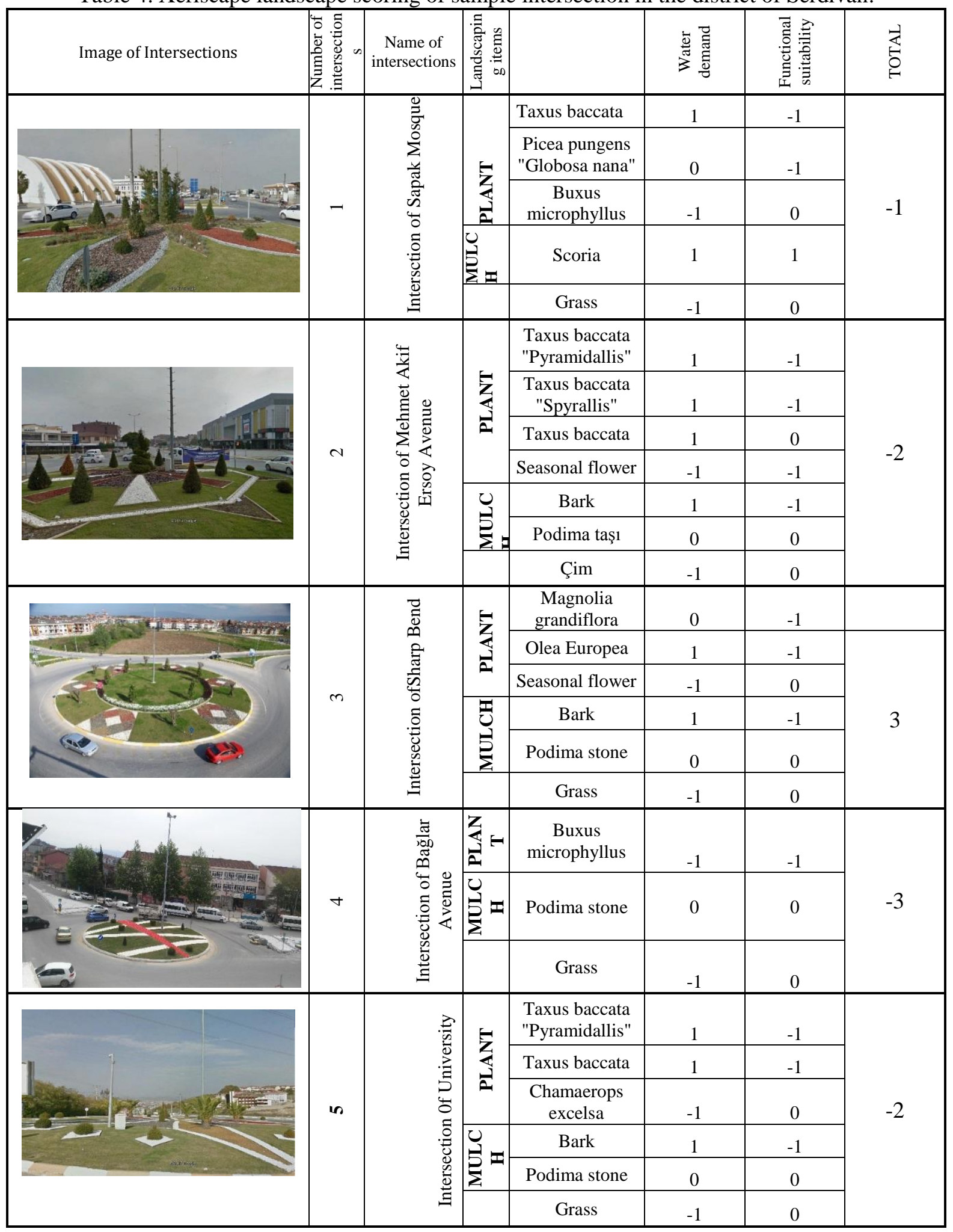


Water demand : + 1 low , 0 middle, -1high; Functional suitability: +1 available, 0 middle , -1 not available

When watering 35 days a year, $35 \times 11.8=413$ tons of annual water is needed. In this case, 1239 (1652-413) tons of water was saved annually when a thirst- free plant was used in the lawn areas.

The results show that there is a need for irrigation in traffic islands between April-October, especially in July this need is highest. If the application of xeriscaping on the traffic roads is done, it will be an important step to make landscaping by providing a high amount of water saving. Implementation of this on provincial basis will make Sakarya a sample field of water-efficient landscape design. Today's precautions need to be taken in order to prevent the problems that are already starting to be felt from reaching unbearable dimensions in the future. As a result of adoption of the xeriscaping approach in traffic islands; The water footprint will provide low urban open green areas, reduce the carbon footprint of green areas [16], reduce maintenance and irrigation costs so that municipalities can transfer their budget and energy to other services. As the use of chemical insecticides and herbicides is reduced, the amount of harmful substances in the groundwater resources will also decrease [17]. Xeriscape philosophy created by the United Nations Sustainable Development Goals (SDG) and guiding the national and international environmental policy in many countries, including Turkey has the supporting application [12]. Sustainable development objectives supported by elaborate xeriscaping practices; SDG 6: Ensure access to clean water for all, SDG 11: Make settlements safe, resilient and sustainable, SDG 12: Establishment of sustainable consumption and production patterns, SDG 13: Urgent action to combat climate change and impacts, SGD 15: It is to protect the sustainable use of terrestrial ecosystems. Starting from the traffic islands, first the passive green areas and then the active xeriscaping studies in active green areas will be the most meaningful step of landscape architects for adaptation and struggle to climate change.

\section{References}

[1] IPCC, CLIMATE CHANGE 2013 The Physical Science Basis Report, Stocker TF, Qin D, Plattner GK, Tignor, MMB, Allen SK, Boshung J, Nauels A, et al., editors, 2013.

[2] UNDP, "Sustainable Development Goals", http://www.undp.org/content/undp/en/home/sustainabledevelopment-goals.html, Access date: 12.01.2018.

[3] Grimmond S., "Urbanization and global environmental change: local effects of urban warming", The Geographical Journal, 173: 1, 2007.

[4] McCarty MP, Best MJ, Betts RA, "Climate change in cities due to global warming and urban effects", Geophysical Research Letters, 37:9, 2010.

[5] Fernandez FJ, Alvarez-Vázquez LJ, García-Chan N, Martínez A, Vázquez-Méndez ME, “Optimal location of green zones in metropolitan areas to control the urban heat island", Journal of Computational and Applied Mathematics, 289: 412-425, 2015.

[6] Zhang Y, Murray AT, Turner BL, "Optimizing green space locations to reduce daytime and nighttime urban heat island effects in Phoenix, Arizona", Landscape and Urban Planning, 2017, 165: 162-171.

[7] Du H, Cai W, Xu Y, Wang Z, Wang Y, Cai Y, "Quantifying the cool island effects of urban green spaces using remote sensing Data", Urban Forestry \& Urban Greening, 27: 24-31, 2017.

[8] Bostanc1 B, "Geometric Design of Traffic Island", 2. Engineering Measurements Symposium, 2005.

[9] Durakovic B, Torlak M, "Experimental and numerical study of a PCM window model as a thermal energy storage unit", International Journal of Low-Carbon Technologies, 12: 272-280, 2017.

[10] SBB, "Sakarya Municipality 2015-2019 Strategic Plan”, 2015.

[11] https://www.google.com.tr/maps/@40.759447,30.3745131,3976m/data=!3m1!1e3 Access date: 05.03.2018.

[12] Demircan M, Demir Ö, Atay H, Yazıcı B, Eskioğlu O, Tuvan A, Akçakaya A, "Climate Change Projections for Turkey by the new scenario", The Climate Change And Climate Dynamics Conference-2014, ITU, 8-10 October 2014.

[13] MGM, "Sakarya Climate data, https://www.mgm.gov.tr/veridegerlendirme/il-ve-ilceleristatistik.aspx?m=SAKARYA, Access date: 15.12.2017. 
[14] Durakovic B, "Design of Experiments Application, Concepts, Examples: State of the Art", Periodicals of Engineering and Natural Sciences, 5:3, 421-439, 2017.

[15] Najifar P, Kurtay C, "Harvesting Feasibility of Rain Water in Buildings", Periodicals of Engineering and Natural Sciences, 6:1, 144-152, 2018.

[16] Mwanza M, Kaoma M, Bowa C K, Çetin N S, Ülgen K, The Potential of Solar Energy for Sustainable Water Resource Development and Averting National Social Burden in Rural Areas of Zambia, Periodicals of Engineering and Natural Sciences, 5:1, 2017.

[17] Findik F, Turan K, "Green Materials and Applications", Periodicals of Engineering and Natural Sciences, 3:2, 2015. 